\title{
Література:
}

1. Сімейний кодекс України від 10.01.2002 р. № 2947-III. Верховна Рада Украйни. Законодавство України. URL: https://zakon.rada.gov.ua/ laws/show/2947-14.

2. Ватрас В.А. Суб'єкти сімейних правовідносин. дис ... канд. юрид. наук: 12.00.03 . К., 2008. 227 с.

3. Слюсар Л.І. Розлучення в Україні в демографічному вимірі: минуле і сучасність. Демографія та соціальна економіка. 2014. № 2 (22). C. $78-89$.

4. В Україні замовчують катастрофу розлучень. Всеукраїнський Собор. URL: https://sobor.com.ua/news/v-ukrayinizamovchuyut-katastrofu-rozluchen.

5. Максимова Н.Ю. Розлучення батьків як фактор девіантної поведінки дітей. URL: http://lib.iitta.gov.ua/705179/1/ Максимова_H.Ю.PDF

DOI https://doi.org/10.30525/978-9934-26-040-7-20

\section{ПРАВОВЕ РЕГУЛЮВАННЯ САМОПРЕДСТАВНИЦТВА ЮРИДИЧНИХ ОСІБ}

\author{
Кондрат'єва Л. А. \\ кандидат юридичних наук, \\ дочент кафедри процесуального права юридичного факультету \\ Чернівецького національного університету імені Юрія Федьковича \\ м. Чернівиі, Украӥна
}

В 2016 році Верховна РадаУкраїни внесла зміни до Конституції України, згідно з якими було введено так звану «адвокатську монополію». Ці зміни передбачали здійснення представництва в судах виключно адвокатами, за винятком справ, перелічених в статті 131-2 Конституції України [1]. Як бачимо, Конституція України закріплює виключне право адвокатів на представництво інтересів особи в суді. Водночас фізичні та юридичні особи можуть представляти себе в суді самостійно. Поняття «самопредставництво» закріплене в процесуальних кодексах: у ЦПК (ст. 58) [2 ]; ГПК (ст. 56) [ 3 ]; КАС (ст. 55) [4]. Аналізуючи вказані процесуальні норми, можна стверджувати, що 
самопредставництво - це самостійна участь особи (фізичної чи юридичної) в судовому процесі, який ведеться від іiі імені та в іiі інтересах.

Якщо самопредставництво фізичної особи не викликає будь-яких дискусійних моментів, то щодо представництва юридичних осіб виникає безліч запитань з огляду на прийняття Закону України «Про внесення змін до деяких законодавчих актів України щодо розширення можливостей самопредставництва в суді органів державної влади, органів влади Автономної Республіки Крим, органів місцевого самоврядування, інших юридичних осіб незалежно від порядку їх створення» від 18.12.2019 р. № 390-IX [5]. Вказаним законом значно розширено перелік осіб, які можуть представляти юридичну особу в порядку самопредставництва. Так, представляти інтереси юридичної особи в рамках господарського, цивільного та адміністративного процесу може будь-який співробітник підприємства (як державної, так і приватної форми власності). Крім керівника підприємства і членів виконавчого органу (наприклад, це може бути виконавчий директор, фінансовий директор) інтереси юридичної особи можуть представляти ще й інші уповноважені особи відповідно до закону, статуту, положення, трудового договору (контракту) тощо. Отже, фактично надано права на представництво в суді штатним юристам, оскільки такі особи не повинні мати свідоцтва про право на зайняття адвокатською діяльністю. Разом з тим, досі є чинною норма Конституції щодо представництва в судах виключно адвокатами. Прийняття цього закону, на нашу думку, ставить під сумнів подальше існування «адвокатської монополії». Підставою так вважати може слугувати те, що 14 січня 2021 року Верховна Рада України попередньо схвалила законопроект № 1013 про скасування норми щодо адвокатської монополії в Конституції України, в якому передбачається, що участь адвоката $\epsilon$ обов'язковою у здійсненні захисту особи від кримінального обвинувачення.

Незважаючи на правову визначеність норм Закону № 390-1X, в ньому відсутній повний перелік осіб, які можуть здійснювати «самопредставництво» юридичної особи та не встановлений перелік документів, які необхідно подати особі до суду, щоб позов чи будьякий процесуальний документ був прийнятий судом; та підтвердити право на здійснення такого представництва 3 метою запобіганню необгрунтованої відмови суду щодо можливості представляти інтереси юридичної особи.

3 огляду на вказане вище, слід звернути увагу на те, що процесуальне законодавство закріплює поділ процесуального 86 
представництва юридичної особи на дві категорії: 1) «самопредставництво юридичної особи» - юридична особа незалежно від порядку іiі створення бере участь у справі через свого керівника, члена виконавчого органу, іншу особу, уповноважену діяти від іiі імені відповідно до закону, статуту, положення, трудового договору (контракту) ; 2) представництво юридичної особи представником (адвокатом), уповноваженого діяти в процесі на підставі довіреності чи ордеру, виданих згідно договору про надання правової допомоги. Так у постанові в господарській справі № 916/914/19 [6] пояснюється, що належним і достатнім доказом на підтвердження повноважень на представництво для адвоката $\epsilon$ довіреність або ордер. Інакше кажучи, повноваження представника на подання та підписання позову підтверджують: 1) договір про надання правової допомоги, підписаний 3 керівником юридичної особи; 2) ордер. У своїй постанові від 5.06.2019 року Велика Палата Верховного Суду вказала, що в ордері має бути зазначена конкретна назва суду, в якому адвокат надає правову допомогу. Проте восьмеро суддів Великої Палати виклали окрему думку щодо правил заповнення ордеру на надання правової допомоги, оскільки вважають, що в ордері достатньо вказати «орган державної влади» [7].

Отже, не може бути допущений до судового розгляду самопредставник, який на підтвердження своїх повноважень надає довіреність, адже цим документом можуть бути підтверджені лише повноваження адвоката. 3 іншого боку, юридична особа може бути представлена юрисконсультом, який працює згідно штатного розкладу на підставі трудового договору або контракту, для цього не потрібно отримувати свідоцтво адвоката. Саме така вимога часто була підставою для повернення або залишення без руху процесуальних документів судом. Так, суддя Касаційного адміністративного суду повернув скаргу особі, яка намагалась підтвердити свої повноваження довіреністю. В ухвалі від 3 лютого у справі № 160/6823/19 суддя зазначив, що особа може діяти в порядку самопредставництва тільки у випадках, якщо в законі, положенні чи трудовому договорі визначене право діяти від імені юридичної особи (суб'єкта владних повноважень) без додаткового уповноваження [8].

Разом $з$ тим, процесуальне законодавство не містить чіткої вказівки щодо підтвердження повноважень особи на самопредставництво юридичної особи, а судова практика в цьому питанні тільки починає формуватися, проте загальні норми (ст. 60 ГПК України, ст. 62 ЦПК України, ст. 59 КАС України) передбачають підтвердження повноважень представника на підставі довіреності. 
Сьогодні досі невирішеним $є$ питання щодо того, якими документами можуть бути підтверджені повноваження особи, що здійснює самопредставництво юридичної особи. 3 метою запобігання відмови суду в допущені осіб, які перебувають в трудових правовідносинах 3 юридичною особою, до здійснення самопредставництва цієї особи або самопредставника юридичної особи допустили до участі в судовому засіданні, необхідно, на нашу думку, подати такі документи:

1. Наказ про прийняття на роботу, трудовий договір, в яких відображається займана посада особи. В трудовому договорі повинно бути зазначено положення, згідно з яким особа займаючи посаду юрисконсульта, наділена повноваженнями на представництво інтересів юридичної особи в суді. Відсутність відповідних положень в трудовому договорі $є$ підставою для відмови в допуску до розгляду справи.

2. Докази, що підтверджують посаду особи та обсяг іiї повноважень. Ними можуть бути: статут, положення, трудовий договір ( контракт).

Разом з тим, слід пам'ятати, що особиста участь у справі особи, яка здійснює самопредставництво юридичної особи, не позбавляє юридичну особу права мати в цій справі представника, тобто адвоката.

\section{Література:}

1. Конституція України. Відомості Верховної Ради. 1996. N 30. Ст. 141 28.06.1996 № 254к/96-ВР (Редакція станом на 01.01.2020) [Електронний pecypc]. URL: https://zakon.rada.gov.ua/laws/show/ 254\%D0\%BA/96-\%D0\%B2\%D1\%80\#Text

2. Цивільний процесуальний кодекс України від 18.03.2004 зі змінами. [Електронний ресурc]. URL: https://zakon.rada.gov.ua/ laws/show/1618-15

3. Господарський процесуальний кодекс України / Законодавство України. Київ: Нотіс. 2021. 196 с.

4. Кодекс адміністративного судочинства України від 06.07.2005 № 2747-IV (Редакція закону від 15.12.2017p [Електронний ресурс]. URL: https://ips.ligazakon.net/document/view/t05_2747?ed=2020_01_0

5. Закон України «Про внесення змін до деяких законодавчих актів України щодо розширення можливостей самопредставництва в суді органів державної влади, органів влади Автономної Республіки Крим, органів місцевого самоврядування, інших юридичних осіб незалежно від порядку їх утворення». Відомості Верховної Ради України. 2020. № 15. Ст. 95.

6. Постанова від 13.09.2019 № 916/914/19 Верховний Суд. Касаційний господарський суд [Електронний ресурс]. URL: https://verdictum.ligazakon.net/document/84214613 
7. Практика Верховного Суду за червень 2019 року [Електронний pecypc]. URL: https://taxlink.ua/ua/court/postanova-verhovnogo-sudu-vid05062019-roku-u-spravi-908156818/

8. Ухвала Касаційного адміністративного суду від 3 лютого у справі № 160/6823/19 [Електронний ресурс]. URL: https://verdictum.ligazakon.net/document/87363581

DOI https://doi.org/10.30525/978-9934-26-040-7-21

ПОХІДНІ ПОЗОВНІ ВИМОГИ В ЦИВІЛЬНОМУ СУДОЧИНСТВІ УКРАЇНИ: ХАРАКТЕРИСТИКА ПРОЦЕСУАЛЬНОГО СТАТУСУ ВІДПОВІДАЧА (НА ПРИКЛАДІ ДЕРЖАВНОГО РЕЄСТРАТОРА)

\author{
Короєд С. О. \\ доктор юридичних наук, дочент, \\ професор кафедри права \\ ЗВО «Університет Короля Данила» \\ м. Івано-Франківськ, Україна
}

Цивільний процесуальний кодекс України в редакції Закону від 3 жовтня 2017 року № 2147-VIII (далі - новий ЦПК) на законодавчому рівні закріпив таке процесуальне поняття, як похідні позовні вимоги, яке вже тривалий час використовувалось в судовій практиці, зокрема у спорах щодо права власності на нерухоме майно та державної реєстрації речових прав на нього. Новий ЦПК похідною позовною вимогою називає вимогу, задоволення якої залежить від задоволення іншої позовної вимоги (основної вимоги) та передбачає можливість їх об'єднання в одній позовній заяві (ч. 1 ст. 188); похідна позовна вимога може бути пред'явлена як до того самого відповідача, так й до різних відповідачів (п. 1 і 2 ч. 2 ст. 188); до похідних позовних вимог новий ЦПК відносить вимоги щодо реєстрації майна та майнових прав, інших реєстраційних дій, які є похідними від спору щодо такого майна або майнових прав (ч. 1 ст. 19, ч. 8 ст. 30). В своїх попередніх наукових публікаціях ми вже встановили, що в цьому випадку законодавець має на увазі такі похідні позовні вимоги, які адресовані іншим суб'єктам (не безпосереднім учасникам спірних цивільних матеріальних правовідносин) та спрямовані на реалізацію рішення суду в частині 